Article

\title{
Turning Filling Material into Proppant for Coalbed Methane in Poland-Crush Test Results
}

\author{
Dariusz Knez *(D), Rafał Wiśniowski ${ }^{\mathbb{D}}$ and Winnie Ampomaa Owusu \\ AGH University of Science and Technology, 30-059 Krakow, Poland; wisniows@agh.edu.pl (R.W.); \\ winnieampomaaowusu@yahoo.com (W.A.O.) \\ * Correspondence: knez@agh.edu.pl; Tel.: +48-126-173-784
}

Received: 4 March 2019; Accepted: 30 April 2019; Published: 13 May 2019

\begin{abstract}
The search for unconventional energy resources such as coalbed methane (CBM) is on the rise in Poland due to the demand for energy resources and protection of the environment. CBM production has a lower impact on the environment when compared with coal production. Its development is known to be cost effective due to its use of shallow depths with large gas quantities. Sand is one of the by-products (waste) from open-pit mining operations. Conventional disposal of this material is achieved by storage in heaps and its deployment as landfill as well as filling material for mine pits. This paper investigates the potential use of sand (filler) as a proppant for hydraulic fracturing in coalbed methane formations in Poland through crush test measurements in both single and cyclic loadings. The crush test helps to identify proppant strength under various load applications. Test results show that the sand qualifies for the $4 \mathrm{~K}$ (maximum allowable stress is $27.58 \mathrm{MPa}$ ) and $3 \mathrm{~K}$ (maximum allowable stress $20.68 \mathrm{MPa}$ ) crush classifications under single and cyclic conditions, respectively. This finding shows the viability and potential of the investigated sand as a proppant for hydraulic fracturing in shallow coalbed methane formations in Poland. Furthermore, its use could help filler-providing companies to maintain their production level and save jobs. Notably, it would contribute to the reduction of environmental problems associated with the management of waste, such as that from open-pit mining operations.
\end{abstract}

Keywords: coalbed methane (CBM); proppant; hydraulic fracturing; open pit waste

\section{Introduction}

National energy security in Poland requires the diversification of international natural gas supplies as well as increases in domestic gas production from both diverse reservoirs and the underground storage (UGS) capacity for different gas compositions [1]. Apart from natural gas, coal remains the most important energy source in Poland. Both the national industry and independent researchers are investigating possibilities that can replace coal combustion by less harmful energy generation methods. They have investigated options such as coalbed methane (CBM), hydrogen, and methanol from coal gasification, both from technical and economical points of view [2,3]. CBM is a potential option. Its production involves the reduction of water pressure inside the bed so that methane adsorbed on the surface of the coal grains is released through desorption and flows to the wellbore. These unconventional gas accumulations are known to store more natural gas in comparison with conventional rocks [4].

Poland has large coal resources and good experience in coalmine methane recovery and usage. Recently, there has been an increase in developing these unconventional gas resources in Poland [5]. The country's coal reserve is located in the Upper and Lower Silesian and Lublin basins [4]. Coalbed methane in the Upper Silesian basin is found at shallow depths of 900-1200 m [6]. Recently, coal production in Poland has declined; accordingly, only a small quantity is exported. Coalbed methane 
production helps to reduce methane released into the atmosphere when compared with coal production. Additionally, the burning of methane is known to release less $\mathrm{CO}_{2}$ into the atmosphere than coal, thereby reducing the gases that contribute to global warming. Furthermore, its production from shallow depths makes drilling easy and cost effective [7]. Its easy storage and low transportation difficulty have also increased the interest in its development. The switch from coal to coalbed methane production would therefore benefit a country such as Poland. The production of unconventional coalbed methane is maintained through drilling techniques (horizontal drilling) and hydraulic fracturing.

Hydraulic fracturing is an important process in the petroleum (oil and gas) industry, particularly for the recovery of hydrocarbons. This process involves the injection of fracturing fluids in the reservoir rock to create fractures. This fluid contains an important additive called proppant which helps to keep these cracks open to ensure flow [8]. Proppants can be natural or man-made; examples include sand and ceramic materials. The design of the fracturing fluid is of high importance for the optimal flow of hydrocarbons. With reference to API (American Petroleum Institute) standards, various laboratory tests are conducted prior to the use of these proppants. One of the tests carried out is known as the crush resistance test. This test can either be done normally or in a cyclic manner [9].

Sand is a natural material that is often produced from operations such as open-pit mining. This by-product is a waste product from the mining of lignite and can be used in filling pits $[10,11]$. The conversion of a waste material from an open-pit mine to a useful material (proppant) would help both the management of waste and contribute to the maintenance of production for companies involved in the production of filling material for coal mines. This paper investigates the potential use of a filler as a suitable proppant for unconventional gas deposits through crush resistance tests under both normal and cyclic loading conditions.

\section{Materials and Methods}

A filling material that is used in the Polish coal mining industry was used for this experiment. The method used was the crush test; this was carried out according to the API RP 19C and PN-EN ISO 13503-2:2010, 2010 standards. Prior to testing, sand was dried in an oven for $24 \mathrm{~h}$. The sieve stack, crush cell, and crush test machine were calibrated to ensure the validity of the results. With reference to Table 1 (material weight is necessary to prepare the same samples for each experiment), a sieve stack of 100/200 mesh was built, and sand proppants were obtained by fetching sand into mesh on the top. This was later subjected to vibration with a duration of $10 \mathrm{~min}$ to aid in the sieving of the sample (Figure 1). The crush test determines the strength of a sample being crushed under particular load conditions. This helps to determine the viability of a material as a proppant for hydraulic fracturing. Natural sands are mostly crushed under stresses not exceeding 34.47 MPa [12]. Proppant masses were determined after sieving, with respect to the standards, by multiplying the bulk density and volume in the crush cell.

Table 1. Proppant Formulation.

\begin{tabular}{ccc}
\hline Sieve Size (Mesh) & Sieve Opening $(\boldsymbol{\mu m})$ & Material Weight $(\mathrm{g})$ \\
\hline 100 & 149 & 0 \\
120 & 125 & 45.16 \\
140 & 105 & 31.30 \\
200 & 74 & 23.54 \\
\hline
\end{tabular}




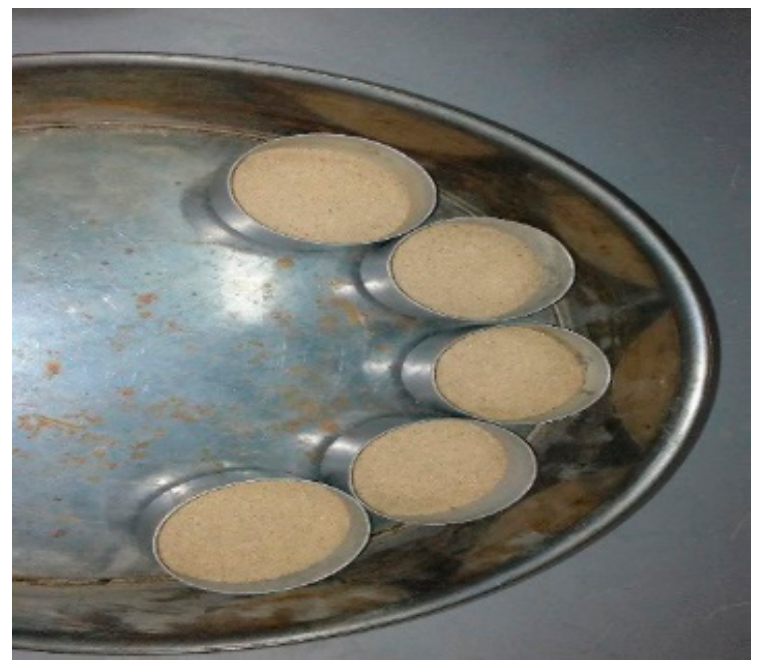

Figure 1. Sand proppants.

The samples obtained were then poured into the crush cell, and the piston of this cell was then inserted gently on the sample and rotated at an angle of $180^{\circ}$ without an application of force. The crush cell and sand proppants were placed carefully in the crush test machine without any agitation. The samples were subjected to crushing up to a maximum stress of $34.47 \mathrm{MPa}$ using hydraulic pressure (Figure 2). During the crushing, the required stress was applied and repeated over a number of cycles on the sample. When more than one cycle was used, this stress level was held for $2 \mathrm{~min}$ and then released before the start of a new cycle. After crushing, the crushed sample was sieved for $10 \mathrm{~min}$, and the crush rate of proppants was determined as a mass ratio of the fines generated to the mass of the proppant before the test.

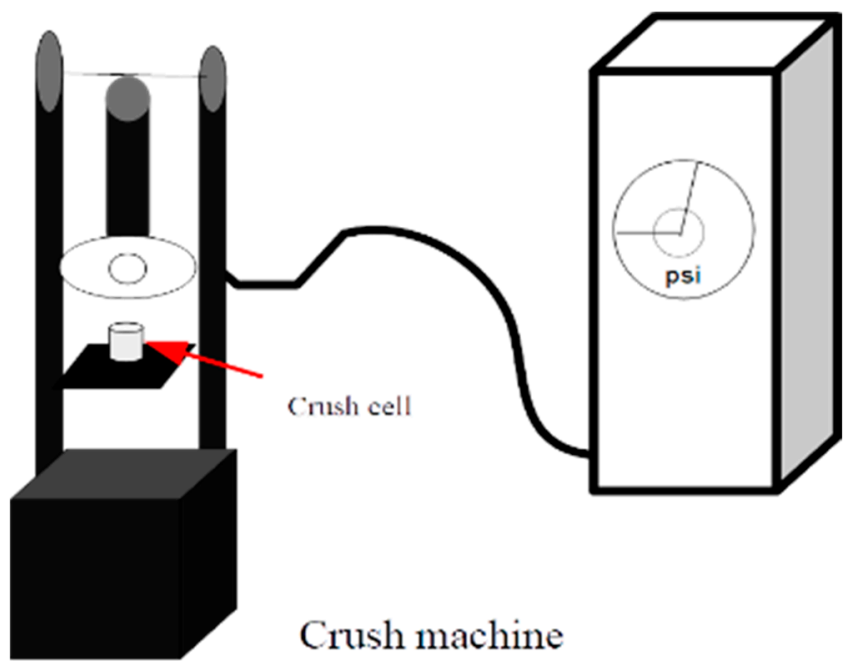

Figure 2. Crush Test.

\section{Results and Discussion}

The crush rate value under a pressure of $27.58 \mathrm{MPa}$ was lower than $10 \%$ (Figure 3); therefore, for single loading, a new proppant can be classified under the $4 \mathrm{~K}$ class. Because the sand proppant passed the crush test with one loading cycle, the next samples were later subjected to a loading test of five cycles under each particular stress. Their respective crush rates are shown in Figure 4. Under cyclic loading with five cycles, all samples passed the crush test with the exception of the sample under $27.58 \mathrm{MPa}$. 


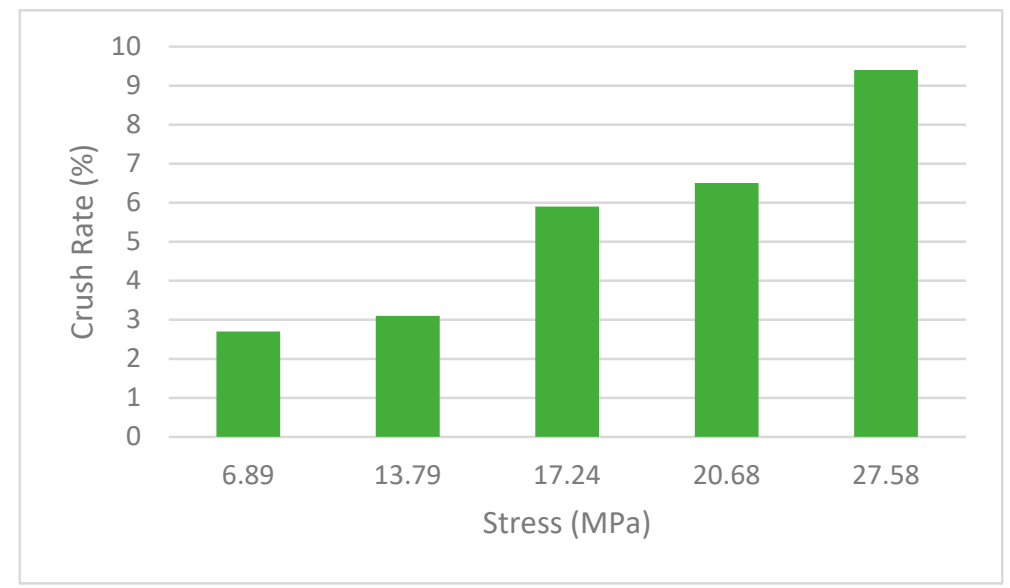

Figure 3. Crush rate with one loading cycle.

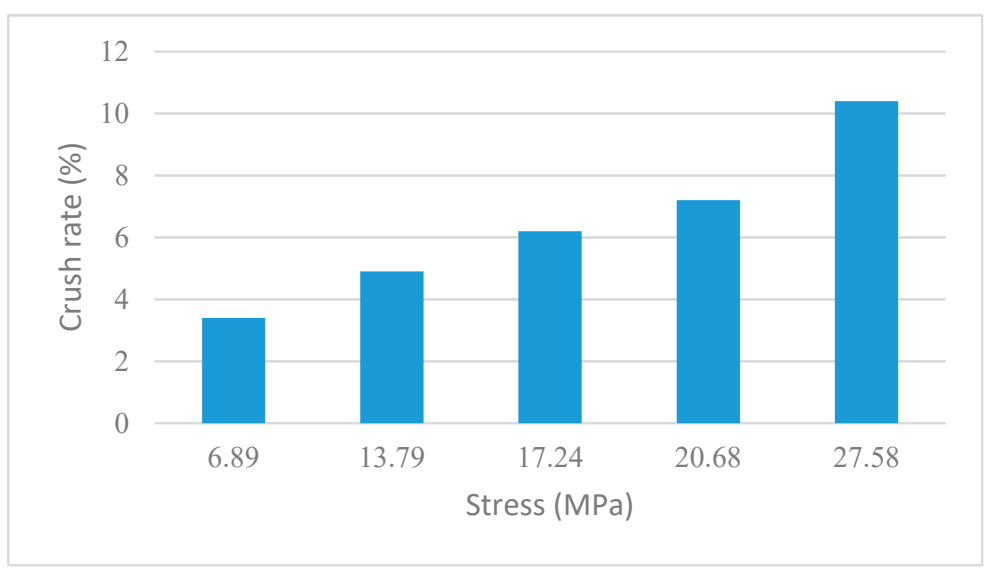

Figure 4. Crush rate with five loading cycles.

The results for proppant samples subjected to $20.68 \mathrm{MPa}$ with 30 cycles of loading are shown in Figure 5. This loading condition had intervals of five cycles, under which each cycle's crush rate was determined. All samples withstood a stress level of $20.68 \mathrm{MPa}$. Accordingly, they were classified under the $3 \mathrm{~K}$ class. According to the API and ISO (International Organization for Standardization) standards, all sand proppants with a weight crush rate $<10 \%$ are considered to have passed the crush resistant test [13].

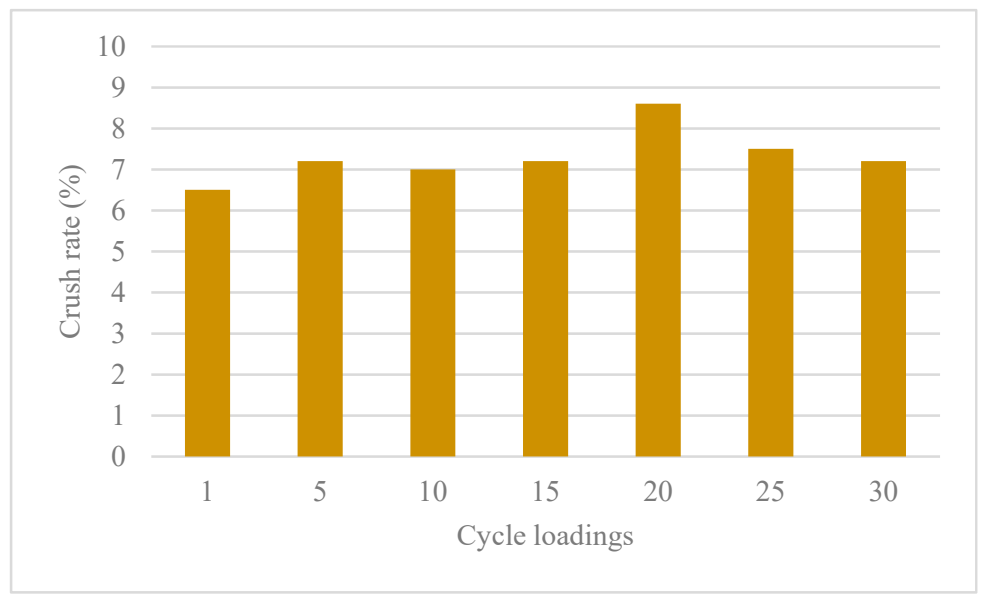

Figure 5. Crush rate at $27.68 \mathrm{MPa}$. 
The filling material had the ability to withstand a stress level of 20.68 MPa and 27.58 MPa under cyclic and normal load conditions, respectively. This classified the material as $3 \mathrm{~K}$ and $4 \mathrm{~K}$, respectively. It also demonstrated its use in formations with shallow depths as a cleaning perforation material or micro proppant. Furthermore, the alternative usage of this filler as a proppant would help to maintain previous levels of production for filler providing companies. This could lead to the availability of more sand for usage as a proppant, thereby helping to reduce the environmental problems caused by waste. Finally, the rise in the need and usage of this material would make use of installed equipment; it would also save jobs, which are known to be decreasing due to the recent decline in coal production in Poland.

\section{Conclusions}

- The proppant made from filling material met the $4 \mathrm{~K}$ classification; however, cyclic loading tests with 5-30 cycles can be classified under the $3 \mathrm{~K}$ class.

- The findings indicate that, after simple sieve processing, the filling material may be applied as potential proppant, which could be used for hydraulic fracturing in shallow formations such as coalbed methane.

- Diversion to coalbed methane production would have a lower environmental impact than coal burning in Poland.

- The use of filling material as a potential proppant would help to maintain the production level of filler providing companies.

- The increase in demand and use of the filling material converted into proppant would allow companies to save jobs.

- $\quad$ Turning filling material into proppant would help to maintain the use of installed production equipment instead of scrapping it.

Author Contributions: D.K. conceptualization; W.A.O. data curation; D.K. formal analysis; R.W. funding acquisition; W.A.O. investigation; D.K. methodology; R.W. project administration; D.K. and R.W. resources; D.K. and R.W. supervision; D.K. and R.W. validation; W.A.O. visualization; W.A.O. writing - original draft; D.K. writing-review and editing.

Funding: This research received no external funding.

Acknowledgments: The project was supported by the AGH subsidy 16.16.190.779 and AGH-UNESCO.

Conflicts of Interest: The authors declare no conflict of interest.

\section{References}

1. Blicharski, J.; Rybicki, C. The gas mixing process in underground gas storages-The "Wierzchowice" UGS case. Arch. Min. Sci. 2008, 53, 53-62.

2. Kopacz, M.; Kwasniewski, K.; Grzesiak, P.; Kaplan, R.; Kryzia, D. Economic assessments of hydrogen production by coal gasification. Przemysl Chem. 2016, 95, 241-249.

3. Kopacz, M.; Kwasniewski, K.; Grzesiak, P.; Kaplan, R.; Kryzia, D. Economic assessment of methanol production by coal gasification. Przemysl Chem. 2016, 95, 130-137.

4. Nawrat, S.; Napieraj, S. Utilization of the methane from polish mines. AGH J. Min. Geoeng. 2012, 36, $269-282$.

5. Blicharski, J.; Szczepaniec, M.; Rybicki, C. Use of conventional hydrodynamic tests to determine the petrophysical properties of unconventional tight gas reservoirs. Przemysl Chem. 2018, 97, 867-870.

6. Stopa, J.; Nawrat, S.; Rychlicki, S. Possibilities of the Methane Utilization from Mined and Unmined Coal Seams in Poland. In Proceedings of the SPE EUROPEC/EAGE Annual Conference and Exhibition, Barcelona, Spain, 14-17 June 2010.

7. Bryner, G.C. Coalbed methane development: The costs and benefits of an emerging energy resource. Nat. Resour. J. 2003, 43, 520-560.

8. Economides, M.J.; Nolte, K.G. Reservoir Stimulation, 3rd ed.; Wiley: Baffins Lane, Chichester, 2000. 
9. Freeman, E.R.; Anschutz, D.A.; Richards, A.R.; Callanan, M.J. Modified API/ISO Crush Tests with a Liquid-Saturated Proppant Under Pressure Incorporating Temperature, Time and Cyclic Loading: What Does It Tells Us? In Proceedings of the SPE Hydraulic Fracturing Technology Conference, Woodlands, TX, USA, 19-21 January 2009.

10. Sivakugan, N.; Veenstra, R.; Naguleswaran, N. Underground mine back filling in australia using paste fills and hydraulic fills. Int. J. Geosynth. Ground Eng. 2015, 1, 1-7. [CrossRef]

11. Sofranko, M.; Wittenberger, G.; Skvarekova, E. The usability of wastes in the backfill management. Inzynieria Mineralna 2015, 1, 75-84.

12. Knez, D.; Calicki, A. Looking for a new source of natural proppants in Poland. Bull. Pol. Acad. Sci. Tech. Sci. 2018, 66, 3-8.

13. Getty, J.; Bulau, C.R. Are the Laboratory Measurement of Proppant Crush Resistance Unrealistically Low? In Proceedings of the SPE Unconventional Resources Conference, Woodlands, TX, USA, 1-3 April 2014.

(C) 2019 by the authors. Licensee MDPI, Basel, Switzerland. This article is an open access article distributed under the terms and conditions of the Creative Commons Attribution (CC BY) license (http://creativecommons.org/licenses/by/4.0/). 